\title{
PENGEMBANGAN MODUL PEMBELAJARAN ALJABAR LINIER DENGAN TAHAPAN 4ME UNTUK PENGEMBANGAN KARAKTER 4C'S MAHASISWA
}

\author{
Endang Suprapti ${ }^{1}$, Himmatul Mursyidah ${ }^{2}$ \\ ${ }^{1,2}$ Universitas Muhammadiyah Surabaya, \\ endang.pendmat@fkip.um-surabaya.ac.id ${ }^{1}$ \\ himmatul.pendmat@fkip.um-surabaya.ac.id ${ }^{2}$
}

\begin{abstract}
ABSTRAK
Modul merupakan salah satu alternatif alat bantu mengajar yang mendukung pembelajaran mahasiswa. Namun, masih banyak modul yang belum sesuai dengan kondisi mahasiswa. Selama ini modul cenderung digunakan untuk pencapaian kognitif, menyampaikan materi, pemberian contoh soal, latihan, dan tes. Sehingga peran modul masih sebatas bagaimana mahasiswa dapat memahami suatu konsep/materi yang terkandung dalam modul tersebut tanpa memperhatikan bagaimana karakter yang muncul dalam diri mahasiswa. Dengan kata lain, modul hanya sebagai pengganti peran dosen sebagai sumber belajar dan pemanfaatan dalam pengembangan karakter mahasiswa masih kurang maksimal. Penelitian ini secara umum bertujuan untuk menyusun modul pembalajaran aljabar linier dengan tahapan $4 \mathrm{Me}$ (Memahami, Menyelesaikan, Membandingkan dan mendiskusikan, serta Menyimpulkan) pada suatu topik permasalahan. Sementara secara khusus penelitian ini untuk mengembangkan karakter 4C's mahasiswa melalui penggunaan modul pembelajaran dengan tahapan 4Me pada mata kuliah Aljabar Linier. 4C's (Critical thingking and problem solving skills, Communication skills, Collaboration skill, Creativity and innovation skill) merupakan keterampilan yang perlu dikembangkan dalam rangka menghadapi kehidupan di era global dan abad 21. Berdasarkan hasil pengembangan perangkat pembelajaran dengan menggunakan model 4-D, dihasilkan perangkat pembelajaran berupa modul pembelajaran, RPP dan instrumen penilaian adalah baik/valid.
\end{abstract}

Kata kunci: aljabar linier, karakter 4C's, modul pembelajaran

\begin{abstract}
Module is one of the alternative teaching aids that support student learning. However, there are still many modules that have not been in accordance with the conditions of students. During this time the module tends to be used for cognitive achievement, delivering material, giving examples of problems, exercises, and tests. So the role of the module is still limited to how students can understand a concept/material contained in the module regardless of how the characters appear in students. In other words, the module only as a substitute for the role of lecturers as a source of learning and utilization in developing the character of students is not maximal. This research generally aims to develop a linear algebra learning module using $4 M e$ steps i.e. Memahami, Menyelesaikan, Membandingkan dan mendiskusikan, and Menyimpulkan (understanding, completing, comparing and discussing, and concluding) on a topic of concern. While specifically this research is to develop the 4C's student character by using learning module with 4Me steps in Linear Algebra course. 4C's (Critical thinking and problem solving skills, Communication skills, Collaboration skills, Creativity and innovation skills) are skills that need to be developed in order to face life in global era and $21^{\text {st }}$ century. Based on the learning device development using 4-D model result, the learning device is produced in the form of learning module, RPP and assessment instrument is good/valid.
\end{abstract}

Keywords: linear algebra, 4C's character, learning module 


\section{PENDAHULUAN}

Modul telah banyak dibicarakan sebagai salah satu alternatif alat bantu mengajar yang mendukung pembelajaran mahasiswa. Penggunaan modul merupakan salah satu cara yang digunakan agar membuat mahasiswa aktif dan termotivasi dalam pelaksanaan pembelajaran. Modul merupakan bahan ajar mandiri yang memuat serangkaian pengalaman belajar, yang disusun, secara sistematis dan dapat membantu siswa mencapai tujuan belajar (Lestari, 2013). Dengan demikian modul dapat membuat mahasiswa aktif dan tidak bergantung pada dosen karena kegiatan pembelajaran disusun secara sistematis. Selain modul disusun secara sistematis, modul juga disusun dengan bahasa yang mudah dipahami dan didesain semenarik mungkin sehingga tidak membuat mahasiswa bosan dengan materi yang dibahas dalam modul.

Selama ini banyak pembelajaran di perkuliahan mahasiswa yang menggunakan modul sebagai bahan ajar. Akan tetapi, masih banyak modul yang belum sesuai dengan kondisi mahasiswa yang diinginkan. Selama ini modul cenderung digunakan untuk pencapaian kognitif, menyampaikan materi, pemberian contoh soal latihan dan tes. Sehingga peran modul masih sebatas bagaimana mahasiswa dapat memahami suatu konsep/materi yang terkandung dalam modul tersebut tanpa memperhatikan bagaimana karakter yang muncul dalam diri mahasiswa. Dengan kata lain, modul hanya sebagai pengganti peran dosen sebagai sarana sumber belajar sehingga pemanfaatannya masih kurang maksimal dalam pengembangan karakter mahasiswa.

Sejalan dengan kurikulum perguruan tinggi yang berjalan, perguruan tinggi menerapkan Kerangka Kualifikasi Nasional Indonesia (KKNI) menurut Peraturan Presiden No.8/2012. KKNI kerangka penjenjangan kualifikasi kerja yang menyandingkan, menyetarakan, mengintegrasikan, sektor pendidikan dan pelatihan serta pengalaman kerja dalam rangka pemberian pengakuan kompetensi kerja sesuai dengan jabatan kerja di berbagai sektor (Presiden Republik Indonesia, 2012). Lulusan Sarjana S1 dan D4 setara dengan level 6 yang mana diharapkan mempunyai kemampuan: (1) Mampu memanfaatkan IPTEKS dalam bidang keahliannya, dan mampu beradaptasi terhadap situasi yang dihadapi dalam penyelesaian masalah, (2) Menguasai konsep teoritis bidang pengetahuan tertentu 
secara umum dan konsep teoritis bagian khusus dalam bidang pengetahuan tersebut secara mendalam, serta mampu memformulasikan penyelesaian masalah prosedural, (3) Mampu mengambil keputusan strategis berdasarkan analisis informasi dan data, serta memberikan petunjuk dalam memilih berbagai alternatif solusi, dan (4) Bertanggung jawab pada pekerjaan sendiri dan dapat diberi tanggung jawab atas pencapaian hasil kerja organisasi. Berdasar pada kemampuan level 6 tersebut maka lulusan S1 dituntut memiliki kompetensi untuk landasan kepribadian, kompetensi dalam iptek, keterampilan dalam menghadapi masalah dan sikap.

Kompetensi yang harus dimiliki oleh lulusan tersebut, didukung oleh Peraturan Pemerintah RI nomor 17 tahun 2010, pasal 97 yaitu (1) Kurikulum perguruan tinggi dikembangkan dan dilaksanakan berbasis kompetensi. (2) Kurikulum tingkat satuan pendidikan untuk setiap program studi di perguruan tinggi dikembangkan dan ditetapkan oleh tiap-tiap perguruan tinggi dengan mengacu Standar Nasional Pendidikan. (3) Kompetensi sebagaimana dimaksud pada ayat (1) paling sedikit memenuhi elemen kurikulum sebagai berikut: a. landasan kepribadian; b. penguasaan ilmu pengetahuan, teknologi, seni, dan/atau olahraga; c. kemampuan dan keterampilan berkarya; d. sikap dan perilaku dalam berkarya menurut tingkat keahlian berdasarkan ilmu dan keterampilan yang dikuasai; dan e. penguasaan kaidah berkehidupan bermasyarakat sesuai dengan pilihan keahlian dalam berkarya (Pemerintah Republik Indonesia, 2010). Dengan kompetensi yang dimiliki tersebut harapan nantinya dapat menghadapi tantangan di era globalisasi.

Berdasarkan kompetensi yang harus dimiliki lulusan, maka sebagai program studi pendidikan matematika di UM Surabaya yang sudah melaksanakan kurikulum 2015 (Kurikulum KKNI) dituntut harus melaksanakan pembelajaran yang dapat membentuk kompetensi tersebut salah satunya pada mata kuliah aljabar linier, menggunakan modul sebagai alternatif media pembelajaran yang diharapkan selain membangun pengetahuan konsep mahasiswa dalam menemukan konsep dan pemecahan masalah, disamping itu diharapkan dapat mengembangkan karakter dasar 4C's. Dalam (As'ari, 2016), National Educational Association atau NEA (tanpa tahun) mengemukakan empat hal yang perlu dikembangkan dalam 
rangka menghadapi abad ke 21 dan era globalisasi itu sebagai 4C's, yaitu: (1) Critical Thinking and Problem Solving Skills (keterampilan berpikir kritis dan pemecahan masalah), (2) Communication Skills (keterampilan komunikasi), (3) Collaboration Skills (keterampilan bekerjasama) dan (4) Creativity and Innovation (kreativitas dan inovasi). Pembelajaran matematika harus mempertimbangkan tuntutan 4C's dalam membantu menyiapkan siswa menghadapi persaingan global. Sehubungan dengan itu, empat karakter disajikan sebagai prioritas untuk dikembangkan agar 4C's dapat tumbuh dan berkembang dengan baik. Keempat karakter prioritas tersebut adalah: (1) cermat dan akurat dalam menyatakan atau merespon informasi, klaim, atau argumen, (2) santun dalam berkomunikasi, (3) respek dalam berkolaborasi, dan (4) gigih serta pantang menyerah dalam berkreasi dan berinovasi.

Untuk mencapai tujuan tersebut, sistematika pengembangan modul ini menggunakan tahapan 4Me (Memahami, Menyelesaikan, Membandingkan dan mendiskusikan, serta Menyimpulkan) pada suatu topik permasalahan. Tahapan tersebut diambil dari langkah-langkah dalam pendekatan pembelajaran Realistic Mathematic Education (RME) yaitu 1) Memahami masalah kontekstual, 2) Menyelesaikan masalah kontekstual 3) Membandingkan atau mendiskusikan jawaban dan 4) Menyimpulkan (Sedangkan untuk karakteristik kelima yaitu, terdapat keterkaitan diantara berbagai bagian dari topik pembelajaran (intertwining) memungkinkan dapat dilakukan pada setiap langkah. Dengan demikian mahasiswa belajar berdasarkan topik permasalahan sehari-hari, kemudian masalah tersebut dipahami, dianalisis untuk diselesaikan, dan dihubungkan dengan konsep aljabar linier yang ada, lalu dibandingkan dan didiskusikan jawaban mereka sehingga dapat dilanjutkan dengan menyimpulkan solusi pada masalah awal yang dihadapi.

\section{TUJUAN PENELITIAN}

Penelitian ini bertujuan untuk meningkatkan pemanfaatan media pembelajaran modul dalam mendukung pembelajaran aljabar linier, selain itu juga untuk mengembangkan modul pembelajaran aljabar linier dengan tahapan 
pendekatan 4Me (Memahami, Menyelesaikan, Membandingkan dan mendiskusikan, serta Menyimpulkan) pada suatu topik permasalahan.

Sedangkan tujuan khusus, untuk mengembangakan karakter 4C's mahasiswa pendidikan matematika, karakter 4C's yang dimaksud adalah empat keterampilan dasar dalam menghadapi tantangan era globlalisasi dan juga dalam mendukung implementasi KKNI dalam perguruan tinggi: (1) Critical Thinking and Problem Solving Skills (keterampilan berpikir kritis dan pemecahan masalah), (2) Communication Skills (keterampilan komunikasi), (3) Collaboration Skills (keterampilan bekerjasama) dan (4) Creativity and Innovation (kreativitas dan inovasi).

\section{TINJAUAN PUSTAKA}

\section{Tahapan 4Me Berdasarkan Langkah-langkah RME}

Pembelajaran matematika realistik pada dasarnya adalah pemanfaatan realita dan lingkungan yang dipahami peserta didik untuk memperlancar proses pembelajaran matematika sehingga mencapai tujuan pendidikan matematika secara lebih baik dari pada masa lalu (Soedjadi, 2001). Maksud dari realita yaitu hal-hal yang nyata atau konkrit yang dapat diamati atau dipahami peserta didik lewat membayangkan. Sedangkan yang dimaksud dengan lingkungan adalah lingkungan tempat peserta didik berada baik lingkungan sekolah, keluarga maupun masyarakat yang dapat dipahami peserta didik. Lingkungan ini disebut juga dengan kehidupan sehari-hari.

\section{Prinsip dan Karakteristik Pembelajaran Matematika Realistik}

Terdapat tiga prinsip kunci pembelajaran matematika realistik (Gravemeijer, 1994) sebagai berikut: 1) Menemukan kembali dengan bimbingan melalui matematisasi progresif (Guided reinvention through progressive mathematizing). Dalam menyajikan materi, siswa harus diberi kesempatan untuk mengalami proses yang sama sebagaimana konsep-konsep matematika ditemukan. Hal ini dilakukan dengan cara memberikan masalah kontekstual yang mempunyai berbagai kemungkinan solusi, dilanjutkan dengan matematisasi. Proses belajar diatur sedemikian rupa sehingga siswa menemukan sendiri konsep atau hasil. 2) 


\section{Endang Suprapti1, Himmatul Mursyidah ${ }^{2}$}

Fenomena yamg bersifat mendidik (Didactical phenomenology). Prinsip kedua ini menekankan pada pentingnya masalah kontekstual untuk memperkenalkan topiktopik matematika kepada siswa. Hal ini dengan mempertimbangkan dua aspek yaitu kecocokan aplikasi masalah kontekstual dalam pembelajaran dan kecocokan dampak dalam proses penemuan kembali bentuk dan model matematika dari masalah kontekstual tersebut. 3) Mengembangkan model sendiri (self developed models). Sewaktu mengerjakan masalah kontekstual siswa mengembangkan model sendiri. Sebagai konsekuensi dari kebebasan yang diberikan kepada siswa untuk memecahkan masalah memungkinkan muncul berbagai model buatan siswa, yang mungkin masih mirip atau jelas terkait dengan masalah kontekstual. Model-model tersebut diharapkan akan berubah dan mengarah kepada bentuk yang lebih baik menuju ke arah pengetahuan matematika formal, sehingga diharapkan terjadi urutan pembelajaran seperti berikut "masalah kontekstual" $\rightarrow$ "model dari masalah kontekstual tersebut" $\rightarrow$ "model ke arah formal" $\rightarrow$ "pengetahuan formal" (Soedjadi, 2001).

Ketiga prinsip tersebut menjadi landasan atau dasar pemikiran pembelajaran matematika realistik. Sedangkan untuk membedakan pembelajaran matematika realistik dengan pembelajaran lainnya, terdapat lima karakteristik yang mangacu pada ketiga prinsip tersebut.

Lima karakteristik pembelajaran matematika realistik tersebut diberikan sebagai berikut (Treffers, 1991) (Gravemeijer, 1994): 1) Menggunakan masalah kontekstual (the use of context). Pembelajaran diawali dengan menggunakan masalah kontekstual, tidak dimulai dari sistem formal. Masalah kontekstual yang diangkat sebagai topik awal pembelajaran harus merupakan masalah sederhana yang "dikenali” oleh siswa. 2) Menggunakan model (use models, bridging by vertical instrument). Penggunaan instrumen-instrumen vertikal seperti modelmodel, skema-skema, diagram-diagram, simbol-simbol dan sebagainya untuk menjadi jembatan antara level pemahaman yang satu ke level pemahaman yang lain. Sewaktu mengerjakan masalah kontekstual, diharapkan siswa mengembangkan model mereka sendiri. 3) Menggunakan kontribusi siswa (students constribution). Kontribusi yang besar dalam proses belajar mengajar diharapkan datang dari konstruksi dan produksi siswa sendiri, yang mengarahkan 
mereka dari metode informal mereka ke arah yang lebih formal. Dengan produksi dan konstruksi, siswa terdorong untuk melakukan refleksi pada bagian yang mereka sendiri anggap penting dalam proses belajar mereka (Streefland, 1991). 4) Interaktivitas (interactivity). Terdapat interaksi yang terus menerus antara siswa yang satu dengan siswa yang lain, juga antara siswa dengan pembimbing, mengenai proses konstruksi yang dilakukan oleh masing-masing, serta hasil dari proses konstruksi tersebut, sehingga setiap siswa mendapatkan manfaat positif dari interaksi tersebut. Siswa bebas untuk bertanya, manyatakan persetujuan atau penolakan pendapat temannya, dan menarik kesimpulan. 5) Terdapat keterkaitan diantara berbagai bagian dari materi pembelajaran (intertwining). Struktur dan konsep matematika saling berkaitan, oleh karena itu keterkaitan antar topik (unit pelajaran) harus dieksplorasi untuk mendukung terjadinya proses belajar mengajar yang lebih bermakna.

Berdasarkan karakteristik RME tersebut, langkah-langkah di dalam kegiatan inti proses pembelajaran matematika realistik dalam pengembangan modul dengan tahapan 4Me pada penelitian ini adalah Langkah 1: Memahami masalah kontekstual. Pada langkah ini sesuai dengan karakteristik pembelajaran matematika realistik yang pertama yaitu, penggunaan konteks nyata. Langkah 2: Menyelesaikan masalah kontekstual. Semua prinsip pembelajaran matematika realistik sesuai dalam langkah ini. Sedangkan karakteristik pembelajaran matematika realistik yang sesuai adalah karakteristik yang kedua, yaitu menggunakan model. Langkah 3: Membandingkan atau mendiskusikan jawaban. Pada langkah ini sesuai dengan karakteristik pembelajaran matematika realistik yang ketiga dan keempat, yaitu penggunaan kontribusi siswa dan terdapat interaksi antara siswa yang satu dengan siswa yang lain. Langkah 4: Menyimpulkan. Pada langkah ini sesuai dengan karakteristik pembelajaran matematika realistik yang keempat yaitu terdapat interaksi antara siswa dengan guru. Sedangkan untuk karakteristik kelima yaitu, terdapat keterkaitan diantara berbagai bagian dari topik pembelajaran (intertwining) memungkinkan dapat dilakukan pada setiap langkah. 


\section{Karakter 4C's (Keterampilan di Era Global)}

Partnership for $21^{\text {st }}$ Century Skills (2008) mengemukakan pentingnya dimiliki beberapa keterampilan agar sukses dalam kehidupan di era global. Pertama, orang perlu memiliki keterampilan berpikir kritis, dan membuat keputusan. Kedua, orang perlu memiliki keterampilan memecahkan masalah yang bersifat kompleks, multi-disiplin, dan open-ended. Ketiga, orang perlu memiliki kreativitas dan keterampilan berpikir enterpreneurship. Keempat, orang perlu memiliki keterampilan menerapkan pengetahuan, informasi, dan kesempatan yang dimilikinya secara inovatif. Kelima, orang perlu memiliki keterampilan untuk menetapkan pilihan yang bijak terkait dengan keuangan dan kesehatannya (A Resource \& Policy Guide, 2008).

Pacific Policy Research Center (2010) mengklasifikasi beberapa keterampilan yang diperlukan dalam abad ke-21. Agar mampu belajar dan melakukan inovasi dengan baik, Pacific Policy Research Center (2010) mengemukakan bahwa setiap orang harus memiliki beberapa keterampilan, yaitu: (1) Communication and Collaboration, (2) Critical Thinking and Problem Solving, (3) Creativity and Innovation. Untuk keperluan kehidupan dan karir, Pacific Policy Research Center (2010) mengemukakan bahwa setiap orang perlu memiliki keterampilan: (1) leadership and responsibility, (2) productivity and accountability, (3) social and cross-cultural skills. Lebih lanjut, Pacific Policy Research Center (2010) menyarankan ditumbuhkembangkannya literasi media, literasi informasi, dan literasi teknologi (Pacific Policy Research Center, 2010).

Uraian di atas menunjukkan beberapa keterampilan yang perlu dikembangkan dalam pembelajaran, termasuk pembelajaran matematika. National Educational Association atau NEA (tanpa tahun) mengemukakan empat hal yang perlu dikembangkan dalam rangka menghadapi abad ke 21 dan era globalisasi itu sebagai 4C's (As'ari, 2016), yaitu: Critical Thinking and Problem Solving Skills (keterampilan berpikir kritis dan pemecahan masalah), Communication Skills (keterampilan komunikasi), Collaboration Skills (keterampilan bekerjasama) dan Creativity and Innovation (kreativitas dan inovasi).

Keterampilan berpikir kritis dan pemecahan masalah yang dimaksudkan adalah: 1) Kemampuan bernalar secara efektif menggunakan berbagai macam 
metode penarikan kesimpulan, baik yang bersifat induktif, deduktif, atau yang lain sesuai dengan situasinya, 2) Keterampilan berpikir sistemik yang mencakup keterampilan menganalisis bagaimana bagian-bagian dari satu kesatuan utuh yang saling berinteraksi untuk menghasilkan luaran yang menyeluruh dalam suatu sistem yang kompleks, 3) Keterampilan membuat keputusan, yang mencakup: (a) keterampilan menganalisis dan menilai klaim, bukti, dan keyakinan, (b) keterampilan menghasilkan sudut pandang lain yang utama, (c) mensintesis dan membuat keterkaitan antar informasi dan argumen, (d) memaknai informasi dan menarik kesimpulan berdasarkan analisis terbaik, (e) melakukan reflektif secara kritis terhadap pengalaman dan proses belajar. 4) Memecahkan masalah berbagai macam masalah yang belum dikenal baik secara biasa maupun secara inovatif, serta mengajukan pertanyaan penting yang bisa digunakan untuk menghasilkan sudut pandang lain yang membuka peluang terselesaikannya masalah tersebut secara lebih baik. Sementara itu, keterampilan komunikasi yang dimaksudkan adalah: 1) Keterampilan mengartikulasikan ide dan pemikirannya secara efektif baik secara lisan, tertulis, ataupun dengan cara lain di dalam berbagai macam konteks. 2) Keterampilan untuk mendengarkan secara efektif guna memahami makna yang dimaksudkan oleh lawan bicaranya (baik yang berbentuk pengetahuan, tata nilai, sikap, maupun maksudnya). 3) Keterampilan untuk menggunakan komunikasi untuk berbagai keperluan (misalnya: memberitahukan, memerintahkan, memotivasi, atau mempengaruhi). 4) Keterampilan menggunakan media dan teknologi, dan mengetahui bagaimana menilai dampak dan keefektifannya di awal. 5) Berkomunikasi secara efektif dalam berbagai macam lingkungan (termasuk dalam lingkungan multilingual maupun lingkungan multikultural).

Keterampilan kolaborasi yang dimaksud adalah: 1) Keterampilan bekerja secara efektif dan penuh respek dengan berbagai macam tim. 2) Keterampilan untuk berkompromi demi tercapainya tujuan bersama. 3) Keterampilan untuk menerima tanggung jawab bersama dalam pelaksanaan pekerjaan tim, dan keterampilan untuk menghargai kontribusi setiap anggota kelompok.

Sedangkan kreatifitas dan inovasi yang dimaksudkan adalah keterampilan berpikir kreatif yang mencakup: (a) keterampilan untuk menggunakan berbagai 
macam teknik untuk menghasilkan ide (misalnya curah pendapat), (b) keterampilan menghasilkan ide baru dan bermanfaat, (c) keterampilan mengelaborasi, memperbaiki, menganalisis, dan menilai ide awal untuk menghasilkan ide baru yang lebih baik. Keterampilan bekerja secara kreatif dengan orang lain yang mencakup: (a) keterampilan mengembangkan, melaksanakan, dan mengkomunikasikan idenya secara efektif kepada orang lain, (b) keterampilan untuk menerima pendapat dan masukan dan menerapkannya dalam kerja kelompok, (c) keterampilan untuk mempertunjukkan keaslian karyanya dalam pekerjaan, dan memahami tantangan pihak lain dalam menerimanya, (d) keterampilan memandang kegagalan sebagai kesempatan untuk belajar dan menyadari bahwa kreativitas dan inovasi menuntut kesabaran dan ketekunan.

\section{METODE PENELITIAN}

Penelitian ini adalah penelitian pengembangan (development research) yang akan menggali informasi tentang perkembangan obyek penelitian dalam waktu tertentu, kemudian dikembangkan. Pendekatan paparan menggunakan deskriptif untuk mendeskripsikan pengembangan dan penggunaan modul pembelajaran mata kuliah aljabar linier. Sedangkan tahapan 4Me digunakan bagaimana membentuk karakter 4C's pada mahasiswa. Model pengembangan yang dijadikan acuan dalam penelitian ini adalah model Thiagarajan. Model Thiagarajan dikenal dengan model 4-D yang dilakukan melalui 4 tahap, yaitu pendefinisian (define), perancangan (design), pengembangan (develop), dan penyebaran (disseminate) (Thiagarajan, 1974).

\section{HASIL PENELITIAN DAN PEMBAHASAN}

\section{Deskripsi Proses dan Hasil Pengembangan Perangkat Pembelajaran}

Penelitian ini bertujuan untuk meningkatkan pemanfaatan media pembelajaran modul dalam mendukung pembelajaran aljabar linier, selain itu juga untuk mengembangkan modul pembelajaran aljabar linier dengan tahapan pendekatan 4Me (Memahami, Menyelesaikan, Membandingkan dan mendiskusikan, serta Menyimpulkan) pada suatu topik permasalahan. Sedangkan 
tujuan khusus, untuk mengembangkan karakter 4C's mahasiswa pendidikan matematika, karakter 4C's yang dimaksud yaitu empat keterampilan dasar dalam menghadapi tantangan era globlalisasi dan juga dalam mendukung implementasi KKNI dalam perguruan tinggi : (1) Critical Thinking and Problem Solving Skills (keterampilan berpikir kritis dan pemecahan masalah), (2) Communication Skills (keterampilan komunikasi), (3) Collaboration Skills (keterampilan bekerjasama) dan (4) Creativity and Innovation (kreativitas dan inovasi). Berdasarkan prosedur pengembangan model 4-D, langkah-langkah pengembangan pada penelitian ini meliputi tahap pendefinisian (define), tahap perancangan (design), tahap pengembangan (develop), dan tahap penyebaran (disseminate).

Proses pengembangan modul pembelajaran dengan tahapan $4 \mathrm{Me}$ mengikuti langkah-langkah model pengembangan 4-D yang dikemukakan oleh Thiagarajan. Keempat langkah tersebut adalah: (a) Define (Pendefinisian), tahap ini terdiri dari analisis awal-akhir, analisis mahasiswa, analisis materi, analisis tugas, dan spesifikasi indikator hasil belajar. Pada tahap analisis awal-akhir diperoleh informasi tentang kurangnya penggunaan media dalam proses pembelajaran serta kurang menunjangnya modul yang digunakan oleh mahasiswa. Pada tahap analisis, diperoleh jumlah mahasiswa pendidikan matematika ada 37 mahasiswa dengan kemampuan heterogen. Berdasarkan hasil belajar tengah semester I tahun pelajaran 2016/2017 dari 37 siswa hanya 47,48\% siswa yang mencapai nilai di atas kriteria cukup. Dalam melakukan analisis materi, peneliti mengambil materi Aljabar Linier. (b) Design (Perancangan), tahap ini terdiri dari pemilihan media, pemilihan format, dan perancangan awal perangkat pembelajaran. Pada tahap pemilihan media dipilih modul berbasis $4 \mathrm{Me}$ dengan hasil rancangan awal perangkat pembelajaran diperoleh RPP, Modul, dan Instrumen Tes. (c) Develop (Pengembangan), tahap ini terdiri dari uji validasi ahli dan uji coba lapangan. Hasil uji validasi oleh para ahli untuk perangkat pembelajaran dinyatakan baik dengan sedikit revisi dan layak digunakan. Hasil validasi para ahli digunakan sebagai dasar untuk melakukan revisi dan penyempurnaan terhadap perangkat pembelajaran. Validator yang memvalidasi perangkat pembelajaran yang dikembangkan terdiri dari tiga orang dengan status 
sebagai dosen di perguruan tinggi. Hasil penilaian umum validator terhadap perangkat pembelajaran dan instrumen penelitian draf I dapat dilihat pada Tabel 1.

Tabel 1. Hasil Penilaian Umum Validator terhadap Perangkat Pembelajaran

\begin{tabular}{|c|c|c|}
\hline No & Perangkat yang divalidasi & Penilaian \\
\hline 1. & RPP & $\begin{array}{l}\text { Baik, dapat digunakan dengan revisi } \\
\text { kecil }\end{array}$ \\
\hline 2. & Modul Pembelajaran & $\begin{array}{l}\text { Baik, dapat digunakan dengan revisi } \\
\text { kecil }\end{array}$ \\
\hline 3. & Tes & $\begin{array}{l}\text { Valid, bahasa dapat dipahami, dapat } \\
\text { digunakan dengan sedikit revisi }\end{array}$ \\
\hline
\end{tabular}

Setelah dilakukan revisi kecil peneliti melakukan uji keterbacaan dan uji coba lapangan untuk mengetahui baik tidaknya perangkat yang telah dikembangkan.

\section{SIMPULAN}

Berdasarkan hasil pengembangan modul pembelajaran Aljabar Linier dengan tahapan 4Me dengan menggunakan model 4-D, dihasilkan perangkat pembelajaran berupa modul pembelajaran, RPP, dan instrumen penilaian adalah baik/valid dengan sedikit revisi, yang berikutnya akan dilakukan revisi dilanjutkan dengan uji coba keterbacaan dan uji coba lapangan.

\section{DAFTAR PUSTAKA}

A Resource \& Policy Guide. (2008). 21st Century Skills, Education \& Competitiveness.

As'ari, A. R. (2016). Pengembangan Karakter dalam Pembelajaran Matematika: Prioritas dalam Rangka Mengembangkan 4C's. Seminar Pendidikan Nasional (SEMDIKNAS) 2016 (pp. 7-21). Surabaya: Program Studi Pendidikan Matematika, FKIP, Universitas Muhammadiyah Surabaya.

Gravemeijer, K. P. (1994). Developing Realistic Mathematics Education. Ultrecht: Freundenthal Institute.

Lestari, I. (2013). Pengembangan Bahan Ajar Berbasis Kompetensi. Padang: Akademia Permata.

Pacific Policy Research Center (2010). 21st Century Skills for Students and Teachers: Research and Evaluation. Kamehameha Schools Research \& Evaluations Division. 
Pemerintah Republik Indonesia. (2010). Peraturan Pemerintah Republik Indonesia Nomor 17 Tahun 2010 tentang Pengelolaan dan Penyelenggaraan Pendidikan. Jakarta: Kementerian Pendidikan Nasional.

Presiden Republik Indonesia. (2012). Peraturan Presiden Republik Indonesia Nomor 8 Tahun 2012 Tentang Kerangka Kualifikasi Nasional Indonesia. Jakarta: Kementerian Riset, Teknologi, dan Pendidikan Tinggi.

Soedjadi, R. (2001). Pemanfaatan Realitas dan Lingkungan dalam Pembelajaran Matematika. National Conference at UNESA (Surabaya State University), 24. Surabaya.

Streefland, L. (1991). Fractions in Realistic Mathematics Education: A Paradigm of Developmental Research. Dordrecht, Netherlands: Springer Science \& Business Media.

Thiagarajan, S. S. (1974). Intructional Development for Training Teachers of Exceptional Children. Minnesota: University of Minnesota.

Treffers, A. (1991). Didactical Background of a Mathematics Program for Primary Education. Realistic Mathematics Education in Primary School, 21-56. 